EXPERIMENTAL STUDY

\title{
Actions of gonadotropin-releasing hormone antagonists on steroidogenesis in human granulosa lutein cells
}

\author{
J M Weiss, K Oltmanns, E M Gürke, S Polack, F Eick, R Felberbaum, K Diedrich and O Ortmann \\ Department of Obstetrics and Gynecology, Medical University Lübeck, 23538 Lübeck, Germany \\ (Correspondence should be addressed to O Ortmann, Department of Obstetrics and Gynecology, Medical University Lübeck, Ratzeburger Allee 160, \\ 23538 Lübeck, Germany; Email: ortmann@medinf.mu-luebeck.de)
}

\begin{abstract}
Objective: GnRH antagonists have recently been introduced for the prevention of premature LH surges during controlled ovarian hyperstimulation $(\mathrm{COH})$. We have here investigated whether the $\mathrm{GnRH}$ antagonists cetrorelix and ganirelix exert effects on ovarian steroidogenesis. Since there is some controversy about the action of GnRH agonists in the human ovary we also tested the effect of triptorelin on steroid production in cultured human granulosa lutein cells.

Methods: Cells were obtained from patients treated with different protocols of $\mathrm{COH}$. In addition to gonadotropins they received triptorelin, cetrorelix, ganirelix or no $\mathrm{GnRH}$ analogue.

Results: Such in vivo treatment did not result in significant effects of triptorelin or the two GnRH antagonists on spontaneous or human chorionic gonadotropin (hCG)-stimulated steroidogenesis. To exclude the possibility that the in vivo treatment might not affect in vitro steroid production because of low or absent peptide activity, we performed in vitro treatments with triptorelin, cetrorelix and ganirelix for up to $96 \mathrm{~h}$. However, these treatment paradigms did not influence basal or hCGstimulated steroid production.

Conclusions: We conclude that GnRH antagonists do not exert any significant effects on ovarian steroidogenesis in vitro and therefore their introduction into protocols of $\mathrm{COH}$ is unlikely to impair ovarian function.
\end{abstract}

European Journal of Endocrinology 144 677-685

\section{Introduction}

Gonadotropin-releasing hormone (GnRH) agonists and the GnRH antagonists cetrorelix and ganirelix are currently used in different protocols of controlled ovarian hyperstimulation $(\mathrm{COH})$ for assisted reproduction techniques to prevent premature luteinizing hormone (LH) surges and thus reduce cancellation rates of $\mathrm{COH}$ cycles (1-6). GnRH antagonists have demonstrated their ability to prevent premature $\mathrm{LH}$ surges with a comparable clinical performance to GnRH agonists $(2,4,5,7-9)$. In contrast to GnRH agonists, which induce an initial rise of gonadotropin secretion (flare-up) before suppression is achieved through desensitization of gonadotrophs, administration of the antagonists leads to a rapid inhibition of $\mathrm{LH}$ release, which results from competitive binding of the antagonists to pituitary GnRH receptors. These compounds are therefore more suitable for the blockage of premature LH surges than the GnRH agonists.

Apart from its pituitary actions GnRH has been shown to bind to specific receptors in a number of extrapituitary tissues (10-15). The recent cloning of the GnRH receptor led to the demonstration of $\mathrm{GnRH}$ receptor gene expression in the human ovary (16-18). However, controversial data exist on GnRH receptors in the human ovary (19-21). Recent observations by Brus et al. (22) indicated that high-affinity ovarian GnRH receptors are present predominantly in ovarian tissue after the LH surge. Unlike in the rat, it is still controversial whether these receptors are functional $(11,13)$. Studies on the actions of GnRH analogues on steroidogenesis in granulosa lutein cells in vitro revealed contradictory effects $(17,23-27)$. Minimal information is available on the actions of $\mathrm{GnRH}$ antagonists in the human ovary (3). Since GnRH antagonists will be more widely used in protocols of $\mathrm{COH}$ in the near future it is important to characterize their ovarian effects, which might be advantageous or detrimental for the treatment goal. Furthermore, such knowledge could enhance our understanding of the physiological role of GnRH in the human ovary.

In the present paper we describe the actions of the two new GnRH antagonists ganirelix and cetrorelix and the GnRH agonist triptorelin on steroidogenesis of human granulosa lutein cells. Since there is controversy about the presence of GnRH receptors in the human ovary we determined the GnRH receptor mRNA 
in granulosa lutein cells that were used for these studies.

\section{Materials and methods}

\section{Protocols of $\mathrm{COH}$}

Human granulosa lutein cells were obtained from patients undergoing in vitro fertilization (IVF)/intracytoplasmic sperm injection (ICSI). Four different stimulation protocols were used for $\mathrm{COH}$. Patients in group A $(n=9)$ were treated with 2 ampoules human menopausal gonadotropin (hMG; Ferring, Kiel, Germany) from day 2 of the cycle. On day 6 the dose of hMG was increased to 3 ampoules and thereafter the amount of hMG was adjusted according to the ovarian response. In group B, patients $(n=20)$ received $3.75 \mathrm{mg}$ D-6-tryptophane-GnRH (triptorelin; Ferring) subcutaneously 14 days before hMG application. The protocol of hMG treatment was the same as in group A. In group $C(n=20)$ patients were treated with 2 ampoules hMG from day 2 of the cycle. From day 7 the GnRH antagonist cetrorelix (ASTA Medica, Frankfurt, Germany) was co-administered subcutaneously with hMG at a dose of $0.25 \mathrm{mg} /$ day as described previously (5). The dose of hMG was adapted to the ovarian response in the same way as in groups $A$ and B. In group $\mathrm{D}(n=14)$ patients were treated as in group $\mathrm{C}$ except that 2 ampoules recombinant follicle-stimulating hormone (FSH; Serono, Freiburg, Germany) and the GnRH antagonist ganirelix (N.V. Organon, Oss, The Netherlands) at a dose of $0.25 \mathrm{mg} /$ day was used instead of cetrorelix. When at least three follicles reached a diameter of $20 \mathrm{~mm}$ each, ovulation was induced by administration of 10000 IU human chorionic gonadotropin (hCG). Transvaginal ovarian puncture was performed $36 \mathrm{~h}$ later. The studies were approved by the ethical committee of the Medical University Lübeck.

\section{Granulosa lutein cell preparation and culture conditions}

Follicular aspirates were gained from patients treated with various protocols of $\mathrm{COH}$ (see above). After collection of oocytes, aspirates were centrifuged at $200 \mathrm{~g}$ for $10 \mathrm{~min}$. The pellet was washed twice in phosphate-buffered saline (PBS) without $\mathrm{Ca}^{2+}$ and $\mathrm{Mg}^{2+}$. The cell pellet was resuspended in PBS, overlayed on Ficoll (Pharmacia, Uppsala, Sweden) and centrifuged at $300 \boldsymbol{g}$ for $20 \mathrm{~min}$. Granulosa lutein cells were aspirated from the interphase and resuspended in Ham's F10 medium containing 10\% fetal calf serum, $100 \mathrm{IU} / \mathrm{ml}$ penicillin, $100 \mathrm{ng} / \mathrm{ml}$ streptomycin and $5 \mu \mathrm{M}$ testosterone. Cells were cultured on multiwell dishes (100 000 cells/well) in 5\% $\mathrm{CO}_{2}, 95 \%$ air and saturated humidity at $37{ }^{\circ} \mathrm{C}$. The viability of the cells was always $>90 \%$ as demonstrated by trypan blue exclusion. (For experimental protocol see also reference 44.)

\section{Effects of in vivo treatments with GnRH analogues}

Cells obtained from patients who were treated with triptorelin, cetrorelix, ganirelix or no GnRH analogue were cultured for different periods to examine the possible actions of $\mathrm{GnRH}$ analogues on steroidogenesis. To test the possibility that the effect of the in vivo treatment with these GnRH analogues is transient, estradiol and progesterone production was determined during the initial $1 \mathrm{~h}$ of the culture period. Thereafter media were collected at 24-h intervals for up to $72 \mathrm{~h}$ for estradiol and progesterone measurements. To investigate whether the in vivo GnRH analogue treatment had an effect on agonist-induced steroid production, cells were stimulated for $6 \mathrm{~h}$ with $1 \mathrm{IU} / \mathrm{ml} \mathrm{hCG}$ at 24-h intervals for up to $96 \mathrm{~h}$.

\section{Effects of in vitro treatments with GnRH analogues}

To exclude the possibility that the in vivo treatment with GnRH analogues does not result in changes of steroidogenesis of cultured granulosa lutein cells because of the absence of peptide activity during the culture period, we employed different in vitro treatment protocols using GnRH agonists and GnRH antagonists. Steroid production was determined in cells that were obtained from patients who had been treated with triptorelin or no GnRH analogue. Such cells were exposed to $1 \mathrm{nmol} / \mathrm{l}$ triptorelin, cetrorelix or ganirelix for up to $96 \mathrm{~h}$. We used such a long culture period because the $\mathrm{COH}$ treatment of the patients includes high doses of exogenous gonadotropins which might down-regulate GnRH receptor expression (17). The prolonged culture period might be sufficient to allow the recovery of GnRH receptors. Estradiol and progesterone release were examined at 24-h intervals. Stimulations with hCG $(1 \mathrm{IU} / \mathrm{ml})$ were performed every $24 \mathrm{~h}$ for $6 \mathrm{~h}$. Controls were present in each culture and each plate.

Steroids were determined by enzyme linked immunosorbent assay (Serono). The sensitivity of the assay was $0.2 \mathrm{ng} / \mathrm{ml}$ and $5 \mathrm{pg} / \mathrm{ml}$ for progesterone and estradiol respectively. Inter- and intra-assay variations were below $10 \%$.

\section{RT-PCR for GnRH receptor}

Total RNA from human granulosa lutein cells that were obtained from different groups of patients was purified by Trizol purification (Gibco-BRL, Eggenheim, Germany). In a one-tube assay, total RNA was reverse transcribed (RT; Superscript II RNase H-Reverse Transcriptase; Gibco-BRL) and amplified using recombinant Thermus aquaticus YT1 (Tac) polymerase (Superscript One Step RT-PCR System; Gibco-BRL) to synthesize cDNA. RNA $(0.5 \mu \mathrm{g})$ was dissolved in $50 \mu \mathrm{l}$ reaction 
mix containing $2.4 \mathrm{mM} \mathrm{MgSO}_{4}$, $0.4 \mathrm{mM}$ dNTP mixture, $0.4 \mu \mathrm{M}$ sense and antisense primers each and 2 units polymerase. For PCR amplification, a sense primer (nucleotides 601 to 621; 5'-TCTAGCAGA CAGCTCTGGACA-3') and antisense primer (nucleotides 832 to 851 ; 5'-GAGTCTTCAGCCGTGCTCTT-3') taken from the published GnRH receptor cDNA (16) were used. The amplicons are derived from exons 2 and 3 after RT. Human $\beta$-actin was used as control. PCR conditions were: $50{ }^{\circ} \mathrm{C}$ for $30 \mathrm{~min}$ for RT followed by $94{ }^{\circ} \mathrm{C}$ for $2 \mathrm{~min}$, and 34 cycles at $94{ }^{\circ} \mathrm{C}$ for $30 \mathrm{~s}, 59{ }^{\circ} \mathrm{C}$ for $30 \mathrm{~s}, 72{ }^{\circ} \mathrm{C}$ for $90 \mathrm{~s}$ followed by a final extension at $72{ }^{\circ} \mathrm{C}$ for $10 \mathrm{~min}$ (Perkin-Elmer Thermocycler Gene Amp 9600, Norwalk, CT, USA). After PCR, an aliquot of the reaction was resolved in a $1.3 \%$ agarose gel stained with ethidium bromide.

\section{Data presentation and statistical analysis}

Each experiment was carried out with granulosa lutein cells from one patient and was performed in triplicate.

Data from 9 to 20 experiments were combined and presented as absolute values for progesterone or expressed in per cent of basal release $(100 \%)$. Treatment groups were analyzed for statistically significant differences by Mann-Whitney U test or by a KruskalWallis test if more than two treatments were tested.

\section{Results}

\section{GnRH receptor and $m R N A$}

The granulosa lutein cells obtained from patients undergoing different protocols of $\mathrm{COH}$ were analyzed by RT-PCR for the expression of GnRH receptor mRNA. A pair of primers was designed based on the human pituitary GnRH receptor cDNA sequence (16) located on different exons (exons 2 and 3). PCR products with the predicted size from pituitary and granulosa lutein cells, but not from skeletal muscle, placental and testicular tissue cDNA were detected (Fig. 1). To exclude the possibility of RNA degradation, an RT-PCR for $\beta$ actin was run in parallel showing the expected $353 \mathrm{bp}$ fragments (data not shown).

\section{Effects of triptorelin on steroid secretion}

Since data on direct actions of GnRH agonists on ovarian function are controversial, we tested the possibility that triptorelin exerts effects on steroidogenesis in cultured granulosa lutein cells. Cells obtained from patients who received triptorelin during $\mathrm{COH}$ secreted slightly lower amounts of progesterone than control cells (no GnRH analogue in vivo) (Fig. 2a). However, this inhibitory action was not statistically significant. There were no significant differences in the estradiol or progesterone response to hCG between treatment groups (Fig. 2b). To exclude the possibility

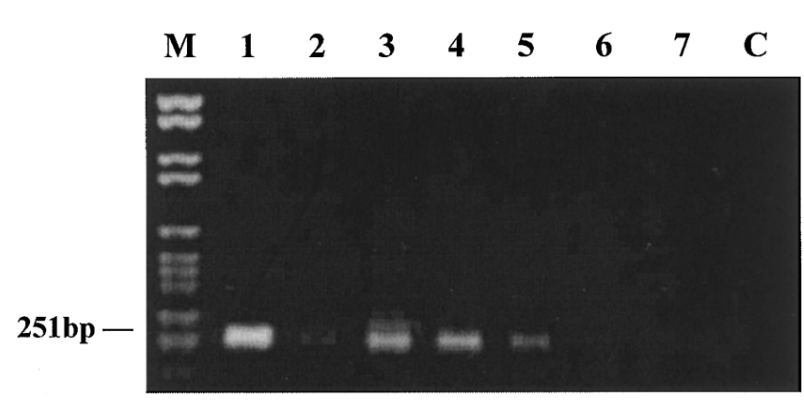

Figure 1 Detection of $\mathrm{GnRH}$ receptor transcript by RT-PCR in human granulosa lutein cells (3-5), pituitary (1), placental tissue (2), musculus rectus (6) and testicular tissue (7). C, control $\left(\mathrm{H}_{2} \mathrm{O}\right)$; $\mathrm{M}, \lambda$ DNA marker.

that the in vivo action of triptorelin cannot be demonstrated after prolonged culture periods we measured estradiol and progesterone release during the initial $1 \mathrm{~h}$ after plating the cells. Even under those conditions, there were no differences between the control, cetrorelix- and triptorelin-treated group (data not shown). There were no differences in estradiol production after all treatment paradigms (data not shown).

\section{Effects of cetrorelix and ganirelix on steroid secretion}

We investigated the effect of cetrorelix and ganirelix treatment on steroidogenesis of granulosa lutein cells and compared them with control or triptorelin treatment. When steroid accumulation was measured in granulosa lutein cells a time-dependent increase was observed. Spontaneous estradiol and progesterone production was not significantly influenced by the $\mathrm{GnRH}$ antagonists. This was the case when GnRH antagonist treatment was compared with control or triptorelin treatments (Fig. 2). As described above, we determined estradiol and progesterone release during the first hour of the culture period after the three different treatment paradigms without any significant effects (data not shown). hCG-stimulated steroid secretion was not influenced by cetrorelix (Fig. 2). Since we intended to exclude the possibility that the actions of cetrorelix might not be present after in vivo treatments, we exposed cells that were obtained from patients who received no GnRH analogue or triptorelin to cetrorelix in vitro. Steroid accumulation was measured up to $96 \mathrm{~h}$ with time-dependent increases of estradiol and progesterone production. There was no significant effect of cetrorelix compared with control or triptorelin treatment (Figs. 3 and 4). Also, hCGstimulated steroid release was not influenced by cetrorelix (Figs. 3 and 4).

In a second series of experiments we used cells from patients that were treated with a $\mathrm{COH}$ protocol that included the application of ganirelix. We did not 
(a)

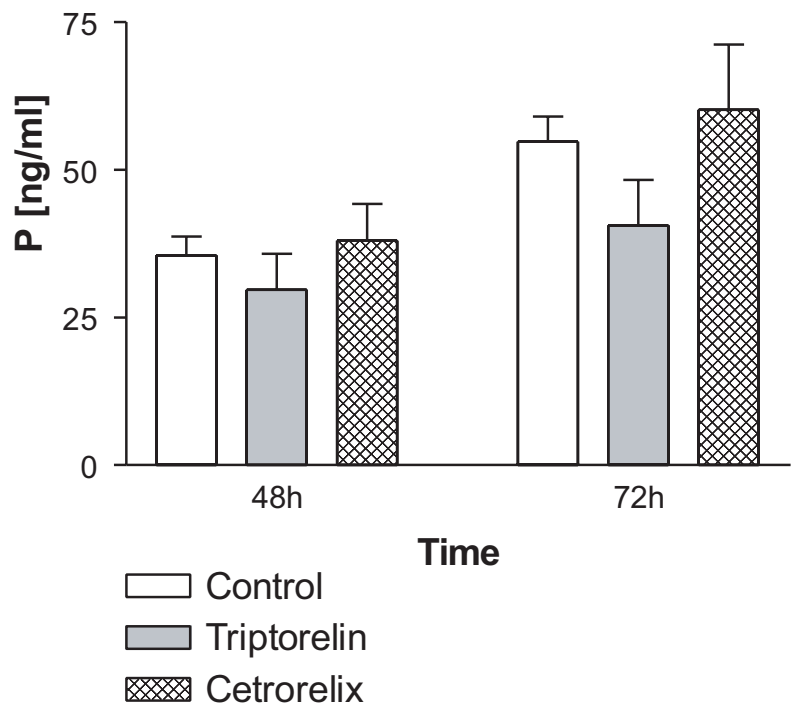

(b) (a)

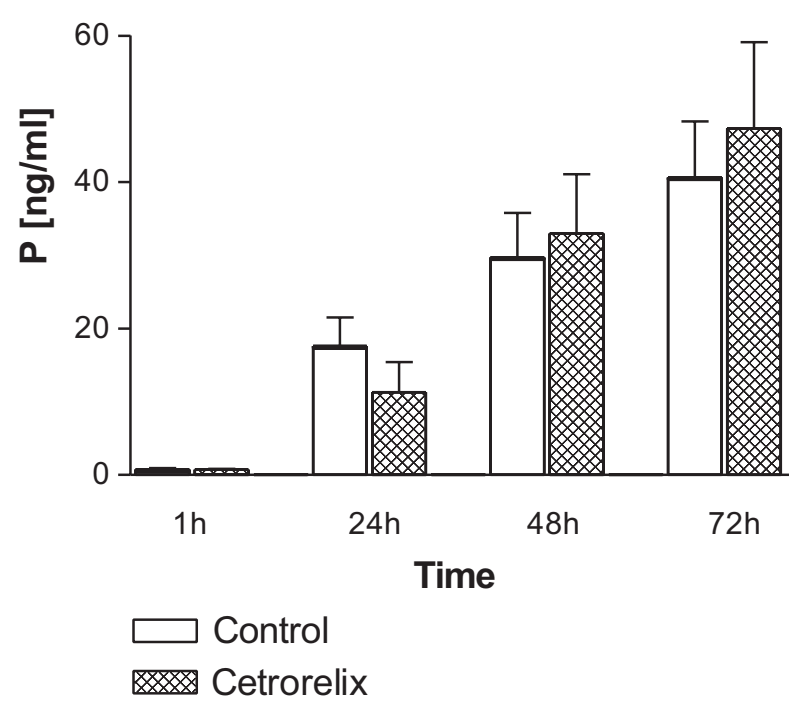

(b)

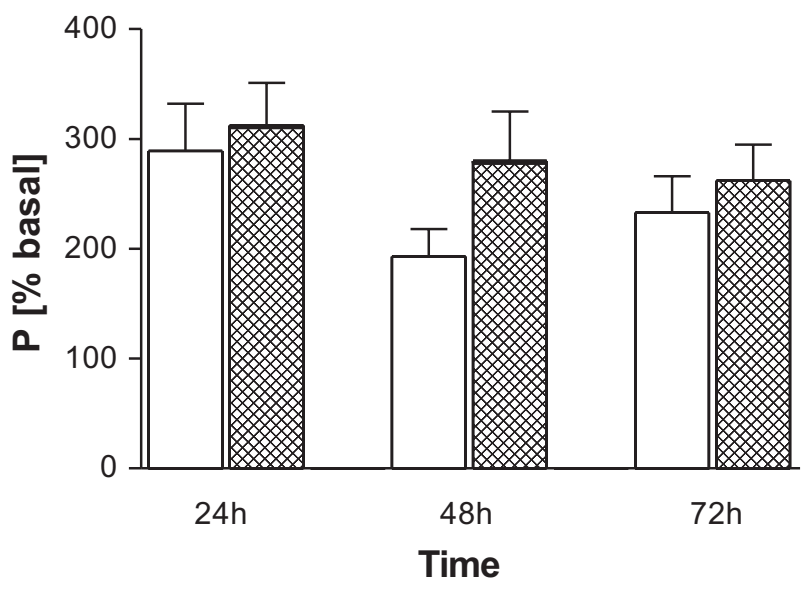

Figure 3 Effects of in vitro treatment with cetrorelix on spontaneous and hCG-stimulated progesterone $(P)$ release from cultured granulosa lutein cells. Cells were obtained from patients treated with triptorelin and cultured for $72 \mathrm{~h}$. (b) Progesterone accumulation was determined at 24-h intervals. (b) hCG stimulation was performed every $24 \mathrm{~h}$ for 6 -h periods. Representative data (means \pm S.E.M.) from 20 experiments at selected time-points are depicted.

\section{Discussion}

In the present study we have investigated the effects of GnRH analogues on steroidogenesis in human granulosa lutein cells. The specific aim was to characterize the actions of the two new GnRH antagonists cetrorelix and ganirelix, the use of which has already been approved for $\mathrm{COH}$ in some countries. The prerequisite for effects of GnRH analogues on steroidogenesis is the presence of GnRH receptors in human ovarian cells. There is consensus that the rodent ovary contains 

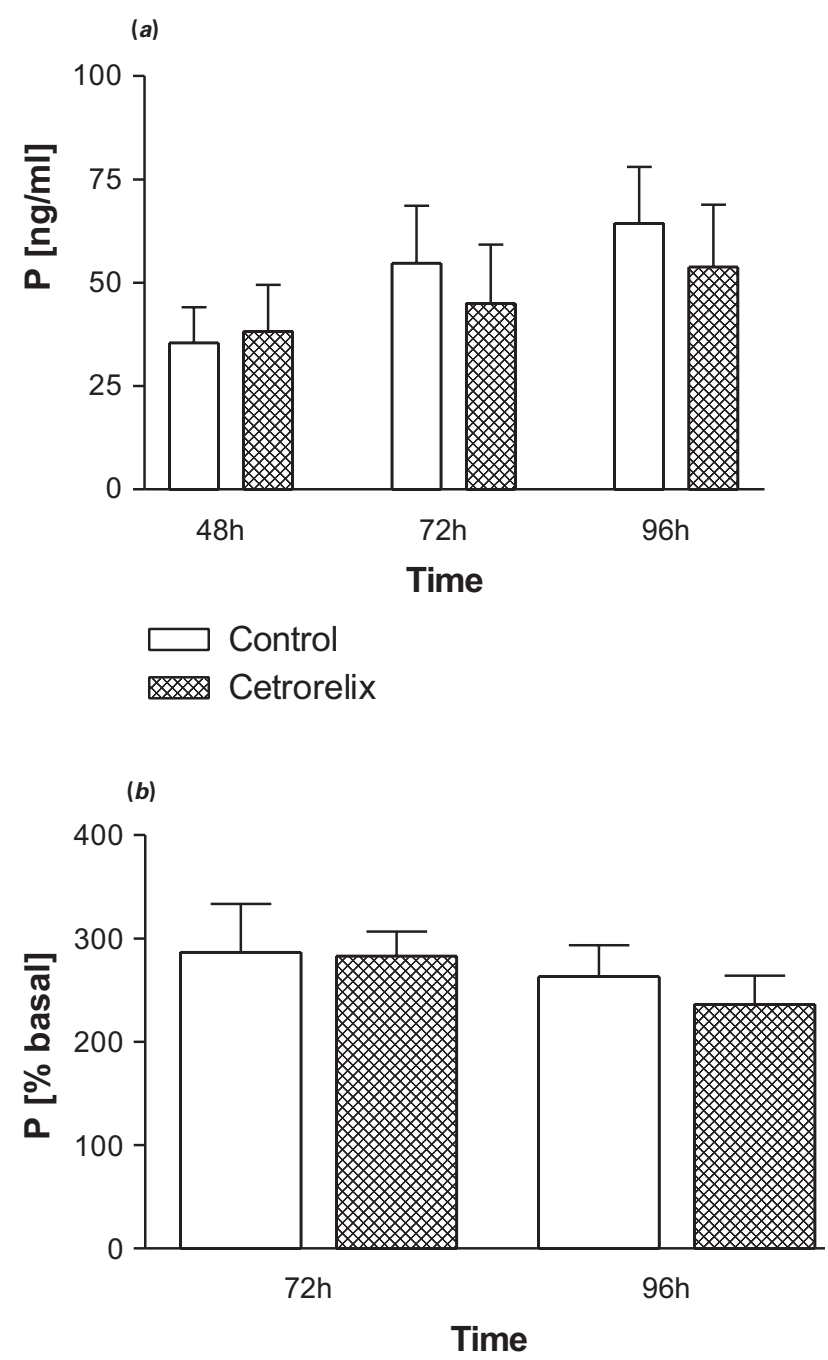

Figure 4 Effects of in vitro treatment with cetrorelix on spontaneous and hCG-stimulated progesterone $(P)$ release from cultured granulosa lutein cells. Cells were obtained from patients treated without any $\mathrm{GnRH}$ analogue and cultured for $72 \mathrm{~h}$. (a) Progesterone accumulation was determined at 24 -h intervals. (b) hCG stimulation was performed every $24 \mathrm{~h}$ for 6 -h periods. Representative data (means \pm S.E.M.) from 9 experiments at selected timepoints are depicted.

GnRH receptors. Conflicting data exist on their expression in the human ovary $(19,21)$. In a careful study by Brus et al. (22), GnRH receptors have been demonstrated in a large proportion of follicular aspirates containing granulosa lutein cells but not in preovulatory follicles, suggesting that GnRH receptors are present in human ovarian tissue predominantly after the LH surge. The expression of the GnRH receptor gene in the human ovary has been shown by several groups $(3,16,17,28)$. GnRH receptor gene expression is up-regulated by GnRH, but down-regulated by hCG (17). The presence of GnRH receptors in human granulosa lutein cells suggests that they mediate the actions of GnRH. However, concentrations of hypothalamic GnRH in the peripheral circulation are much too low to activate these receptors. In contrast, the application of GnRH analogues to patients who undergo $\mathrm{COH}$ results in serum concentrations which are sufficient to interact with the receptors.

Since there was no consensus on the effects of agonistic GnRH analogues on steroidogenesis in the human ovary we compared ganirelix and cetrorelix treatments with triptorelin and control. We found that the administration of the GnRH agonist triptorelin to patients who underwent $\mathrm{COH}$ did not lead to changes in estradiol and progesterone production by granulosa lutein cells obtained from these patients. This was the case when estradiol and progesterone levels were measured in the initial hour or after prolonged culture periods. Since it could be possible that the in vivo exposure of the ovary to GnRH analogues was ineffective because of the absence of the peptide during the culture period we applied the GnRH agonist to the culture medium. Even under these conditions we did not detect any changes in steroid production in the presence of triptorelin either on basal or on hCGstimulated hormone release. These observations confirm those of other authors who were also unable to demonstrate GnRH agonist actions on ovarian steroidogenesis $(24,29-31)$. On the other hand, there have been numerous reports that have shown inhibitory and stimulatory actions of GnRH agonists $(17,23,26,32-$ $35)$. Such controversy might result from differences in experimental conditions, type of GnRH agonist, cells and experimental designs. A few studies which investigated the effect of GnRH agonist treatments in vivo on in vitro steroidogenesis by granulosa lutein cells have demonstrated impaired progesterone production (36-39). In granulosa cells from early to late follicular phase, GnRH or GnRH agonists were without inhibitory action on progesterone secretion $(23,24,26,35)$. The majority of these studies have shown inhibitory action which is astonishing since follicular-phase granulosa cells did not express GnRH receptors in the recent investigation by Brus et al. (22). Interestingly, it seems that certain GnRH agonists exert inhibitory actions while others are inactive (27). In our series of experiments, the GnRH agonist triptorelin showed no effects on steroidogenesis under different experimental conditions.

Limited information is available on the actions of GnRH antagonists in the human ovary. Recently Minaretzis et al. (3) have reported on the effect of the GnRH antagonist Nal-Glu compared with GnRH agonist leuprolide acetate treatment of patients undergoing $\mathrm{COH}$. The progesterone accumulation in granulosa lutein cell cultures was not different between the two groups. Aromatase activity was reduced in the GnRH antagonist-treated group during the first $6 \mathrm{~h}$ of culture. Lin et al. (40) reported on the possibility that the luteal function in GnRH antagonist (cetrorelix) 
(a)

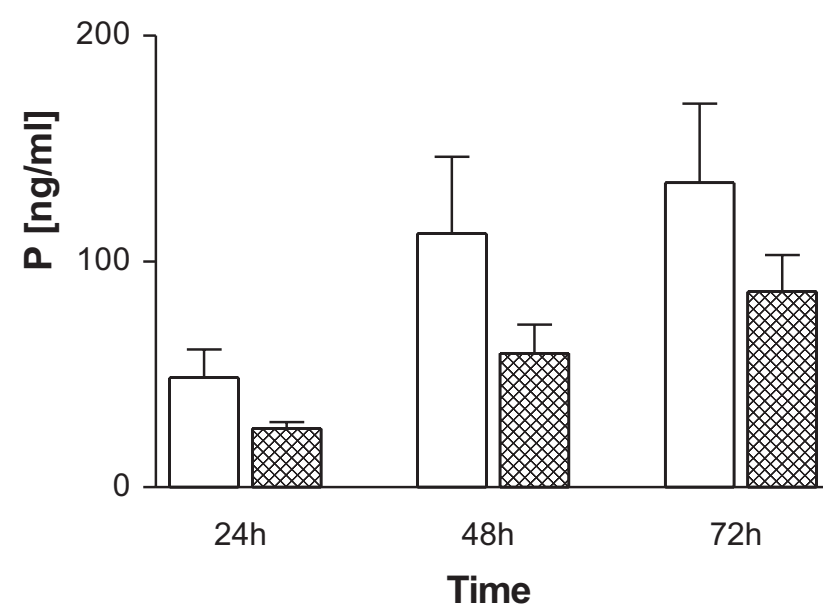

Triptorelin

Ganirelix

(b)

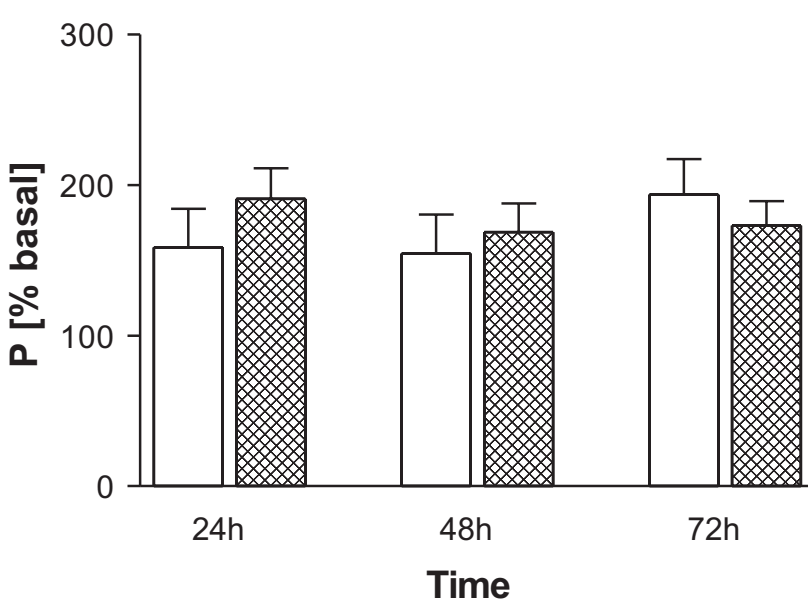

Figure 5 Effects of in vivo treatment with triptorelin and ganirelix on spontaneous and hCG-stimulated progesterone $(P)$ release from cultured granulosa lutein cells. Cells were obtained from patients treated with triptorelin or ganirelix and cultured for $72 \mathrm{~h}$. (a) Progesterone accumulation was determined at $24-h$ intervals. (b) hCG stimulation was performed every $24 \mathrm{~h}$ for 6 -h periods. Representative data (means \pm S.E.M.) from 14 experiments at selected time-points are depicted.

treatment is less impaired compared with control (no GnRH analogue) and GnRH agonists. Both GnRH antagonists had no effect on basal or hCG-induced estradiol or progesterone production by granulosa lutein cells, independent of whether the cells were exposed to the compounds in vitro or in vivo. A recent study by Lin et al. (41) suggested that the luteal function in $\mathrm{GnRH}$ antagonist-treated patients may be less impaired. They compared cetrorelix with GnRH (a)
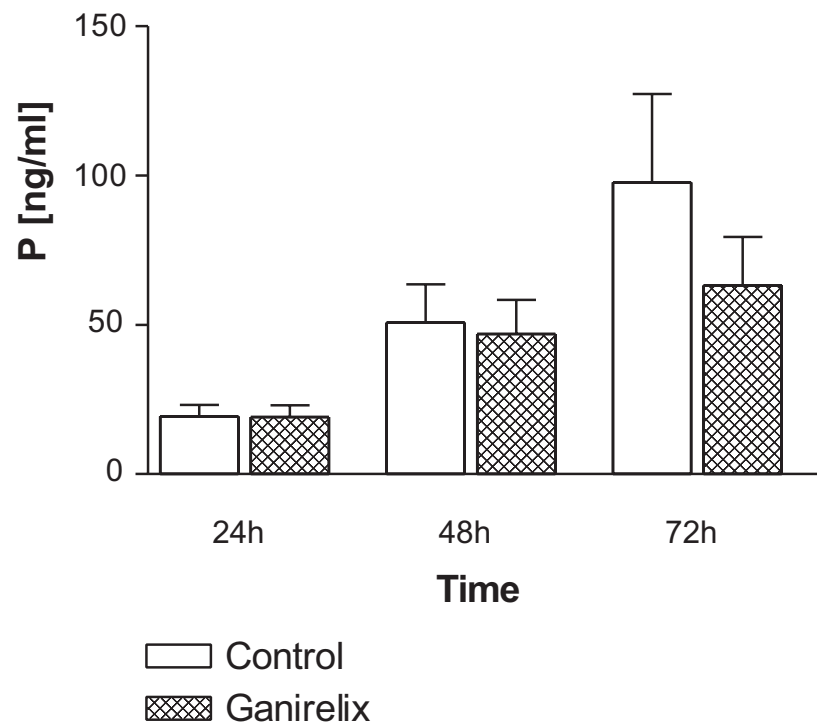

(b)

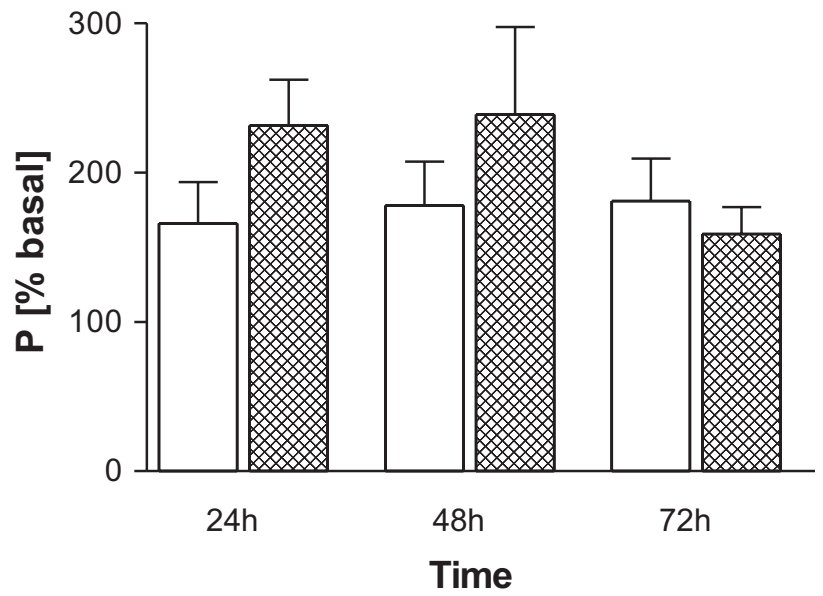

Figure 6 Effects of in vitro treatment with ganirelix on spontaneous and hCG-stimulated progesterone $(P)$ release from cultured granulosa lutein cells. Cells were obtained from patients treated with triptorelin and cultured for 72 h. (a) Progesterone accumulation was determined at 24-h intervals. (b) hCG stimulation was performed every $24 \mathrm{~h}$ for 6 -h periods. Representative data (means \pm S.E.M.) from 20 experiments at selected time-points are depicted.

agonist buserelin and found that cells from patients treated with cetrorelix respond earlier to in vitro hormone stimulation. In the latest study by Dor et al. (42) FSH-induced estradiol production by granulosa lutein cells was significantly lower in patients treated with GnRH agonists compared with patients treated exclusively with hMG for assisted reproduction techniques (ART). However, they could not detect that effect in cells that were not treated with FSH. Nathwani et al. (43) demonstrated, in human granulosa luteal cells, 

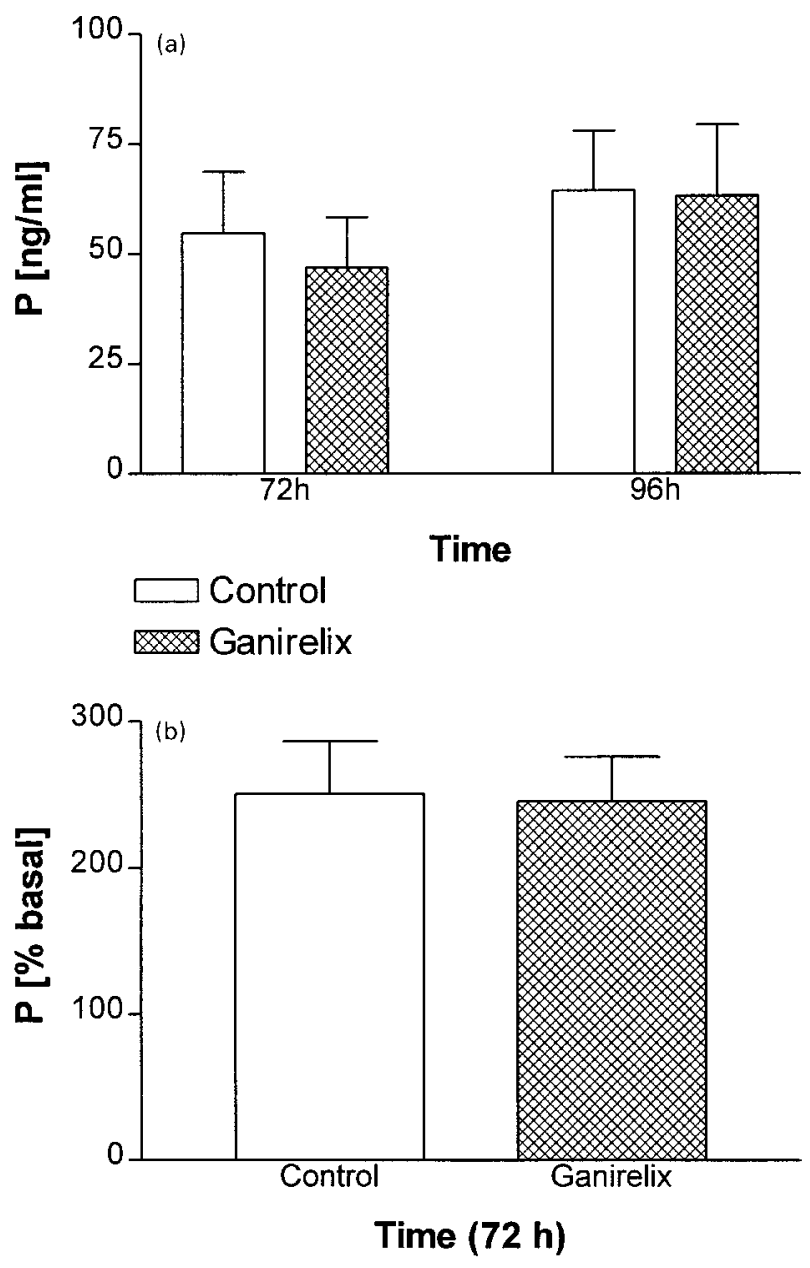

Figure 7 Effects of in vitro treatment with ganirelix on spontaneous and hCG-stimulated progesterone $(P)$ release from cultured granulosa lutein cells. Cells were obtained from patients treated without any $\mathrm{GnRH}$ analogue and cultured for $72 \mathrm{~h}$. (a) Progesterone accumulation was determined at 24-h intervals. (b) hCG stimulation was performed every $24 \mathrm{~h}$ for 6 -h periods. Representative data (means \pm S.E.M.) from 9 experiments at selected time-points are depicted.

that estradiol $(24 \mathrm{~h})$ decreases GnRH mRNA and regulates its receptor gene expression in a biphasic way, such as short-term estradiol treatment $(6 \mathrm{~h})$ enhances and long-term treatment $(48 \mathrm{~h})$ decreases GnRH receptor mRNA levels. If an inhibitory autocrine/paracrine system based on GnRH is present in the human ovary one would assume that steroid production in cultured granulosa lutein cells from women treated with GnRH antagonists would be increased. Obviously data from our experiments do not exclude this possibility because the $\mathrm{COH}$ treatment of the patients includes high doses of exogenous gonadotropins which might down-regulate GnRH receptor expression (17). On the other hand, GnRH antagonists did not affect steroidogenesis after a culture period of 2 days, which might be sufficient to allow recovery of
GnRH receptors. Furthermore, there are reports that have demonstrated $\mathrm{GnRH}$ receptors in granulosa lutein cells from IVF patients that have not been cultured but analyzed by receptor assays directly after retrieval by follicle aspiration (22). These receptors bind the GnRH antagonist D-Tyr-antide and presumably the GnRH antagonists used in the present study (22). Given the fact that granulosa lutein cells express GnRH receptors they do not necessarily mediate GnRH or GnRH antagonist actions on steroidogenesis. For example, in another of our own investigations, we have demonstrated that ganirelix did not exert any effect on cAMP accumulation in human granulosa lutein cells (44). In ovarian and endometrial carcinoma cells, activation of $\mathrm{GnRH}$ receptors leads to antiproliferative effects of GnRH agonists and GnRH antagonists (45). Also, in these cells GnRH receptor activation does not lead to hydrolysis of phosphoinositides by phospholipase $\mathrm{C}$ as in pituitary gonadotrophs but inhibits mitogenic activity and signalling of epidermal growth factor (46). Therefore, the lack of effects of GnRH antagonists on steroidogenesis does not exclude ovarian actions of these compounds in general.

In conclusion, we have demonstrated that the GnRH antagonists cetrorelix and ganirelix do not affect steroidogenesis of human granulosa lutein cells. The absence of such activity, together with the data from recent clinical studies, show that these compounds are unlikely to have detrimental effects on ovarian function of patients who receive cetrorelix or ganirelix in protocols of $\mathrm{COH}$.

\section{Acknowledgements}

The authors gratefully acknowledge Mrs R Sturm, Mrs C Schulz and Mrs R Kohse for their expert technical assistance. Ganirelix was provided by Professor Coelingh-Bennink (N.V. Organon, Oss, The Netherlands). Cetrorelix was donated by Dr Reissmann (ASTA Medica, Frankfurt, Germany).

\section{References}

1 Hughes EG, Fedorkow DM, Daya S, Sagle MA, van de Koppel P \& Collins JA. The routine use of gonadotropin-releasing hormone agonists prior to in vitro fertilization and gamete intrafallopian transfer: a meta-analysis of randomized controlled trials. Fertility and Sterility $1992 \mathbf{5 8} 888-896$.

2 Diedrich K, Diedrich C, Santos E, Bauer O, Zoll C, Al-Hasani S et al. Suppression of the endogenous luteinizing hormone surge by the gonadotrophin-releasing hormone antagonist cetrorelix during ovarian stimulation. Human Reproduction 19949 788791.

3 Minaretzis D, Alper MM, Oskowitz SP, Lobel SM, Mortola JF \& Pavlon SN. Gonadotropin-releasing hormone antagonist versus agonist administration in women undergoing controlled ovarian hyperstimulation: cycle performance and in vitro steroidogenesis of granulosa lutein cells. American Journal of Obstetrics and Gynecology 1995172 1518-1525.

4 Felberbaum RE, Reissmann T, Küpker W, Bauer O, Al-Hasani S, Diedrich $\mathrm{C}$ et al. Preserved pituitary response under ovarian 
stimulation with HMG and GnRH antagonists (Cetrorelix) in women with tubal infertility. European Journal of Obstetrics, Gynecology and Reproductive Biology 199561 151-155.

5 Felberbaum R, Reissmann T, Küpker W, Al-Hasani S, Bauer O, Schill T et al. Hormone profiles under ovarian stimulation with human menopausal gonadotropin (hMG) and concomitant administration of the gonadotropin releasing hormone ( $\mathrm{GnRH})$ antagonist Cetrorelix at different dosages. Journal of Assisted Reproduction and Genetics 199613 216-222.

6 Albano C, Smitz J, Camus M, Riethmüller-Winzen H, van Steirteghem A \& Devroey P. Comparison of different doses of gonadotropin-releasing hormone antagonist cetrorelix during controlled ovarian hyperstimulation. Fertility and Sterility 1997 67 917-922.

7 Weiss JM, Felberbaum R, Montzka P, Ludwig M, Strik D, BalsPratsch $\mathrm{M}$ et al. Controlled ovarian hyperstimulation $(\mathrm{COH})$ with recombinant FSH and concomitant midcyclic GnRH-antagonist treatment (ganirelix) at different dosages. Geburtshilfe und Frauenheilkunde 199859 209-214.

8 Borm G \& Mannaerts B. Treatment with the gonadotropinreleasing hormone antagonist ganirelix in women undergoing ovarian stimulation with recombinant follicle stimulating hormone is effective, safe and convenient: results of a controlled, randomized, multicentre trial. The European Orgalutran Study Group. Human Reproduction 200015 1490-1498.

9 Olivennes F, Belaisch-Allart J, Emperaire JC, Dechaud H, Alvarez S, Moreau L et al. Prospective, randomized, controlled study of in vitro fertilization-embryo transfer with a single dose of a luteinizing hormone-releasing hormone (LH-RH) antagonist (cetrorelix) or a depot formula of an LH-RH agonist (triptorelin). Fertility and Sterility $2000 \mathbf{7 3} 314-320$.

10 Clayton RN, Harwood JP \& Catt KJ. Gonadotropin-releasing hormone analogue binds to luteal cells and inhibits progesterone production. Nature $1979 \mathbf{2 8 2}$ 90-92.

11 Hsueh AJ \& Jones PB. Extrapituitary actions of gonadotropinreleasing hormone. Endocrine Reviews 19812 437-461.

12 Bramley TA, McPhie CA \& Menzies GS. Human placental gonadotrophin-releasing hormone (GnRH) binding sites: III. Changes in GnRH binding levels with stage of gestation. Placenta $199415733-745$.

13 Stojilkovic SS \& Catt KJ. Expression and signal transduction pathways of gonadotropin releasing hormone receptors. Recent Progress in Hormone Research 199530 161-205.

14 Bauer-Dantoin AC \& Jameson JL. Gonadotropin-releasing hormone receptor messenger ribonucleic acid expression in the ovary during the rat estrous cycle. Endocrinology 1995136 $4432-4438$.

15 Chegini N, Rong H, Dou Q, Kipersztok S \& Williams RS. Gonadotropin-releasing hormone (GnRH) and GnRH receptor gene expression in human myometrium and leiomyomata and the direct action of GnRH analogs on myometrial smooth muscle cells and interaction with ovarian steroids in vitro. Journal of Clinical Endocrinology and Metabolism 199681 3215-3221.

16 Kakar SS, Musgrove LC, Devor DC, Sellers JC \& Neill JD. Cloning, sequencing, and expression of human gonadotropin releasing hormone (GnRH) receptor. Biochemical and Biophysical Research Communications 1992189 289-295.

17 Peng C, Fan NC, Ligier M, Vaananen J \& Leung PC. Expression and regulation of gonadotropin-releasing hormone $(\mathrm{GnRH})$ and GnRH receptor messenger ribonucleic acids in human granulosa-luteal cells. Endocrinology 1994135 1740-1746.

18 Minaretzis D, Jakubowski M, Mortola JF \& Pavlon SN. Gonadotropin-releasing hormone receptor gene expression in human ovary and granulosa lutein cells. Journal of Clinical Endocrinology and Metabolism $1995 \mathbf{8 0} 430-434$.

19 Clayton RN \& Huhtaniemi IT. Absence of gonadotropin-releasing hormone receptors in human gonadal tissue. Nature 1982299 56-59.

20 Bramley TA, Menzies GS \& Baird DT. Specific binding of gonadotrophin-releasing hormone and an agonist to human corpus luteum homogenates: characterization, properties, and luteal phase levels. Journal of Clinical Endocrinology and Metabolism $198561834-841$.

21 Latouche J, Crumeyrolle-Arias M, Jordan D, Kopp N, AugendreFerrante B, Cedard L et al. GnRH receptors in human granulosa cells: anatomical localization and characterization by autoradiographic study. Endocrinology 1989125 1739-1741.

22 Brus L, Lambalk CB, de Koning J, Helder MN, Janssens RM \& Schoemaker J. Specific gonadotrophin-releasing hormone analogue binding predominantly in human luteinized follicular aspirates and not in human pre-ovulatory follicles. Human Reproduction 199712 769-773.

23 Tureck RW, Mastroianni L Jr, Blasco L \& Strauss JF III. Inhibition of human granulosa cell progesterone secretion by a gonadotropin-releasing hormone agonist. Journal of Clinical Endocrinology and Metabolism $1982 \mathbf{5 4} 1078-1080$.

24 Casper RF, Erickson GF, Rebar RW \& Yen SS. The effect of luteinizing hormone-releasing factor and its agonist on cultured human granulosa cells. Fertility and Sterility 198237 406-409.

25 Casper RF, Erickson GF \& Yen SS. Studies on the effect of gonadotropin-releasing hormone and its agonist on human luteal steroidogenesis in vitro. Fertility and Sterility $1984 \mathbf{4 2} 39-$ 43.

26 Parinaud J, Beaur A, Bourreau E, Vicitez G \& Pontonnier G. Effect of a luteinizing hormone-releasing hormone agonist (Buserelin) on steroidogenesis of cultured human preovulatory granulosa cells. Fertility and Sterility $1988 \mathbf{5 0} 597-602$.

27 Bussenot I, Azoulay Barjonet C \& Parinaud J. Modulation of the steroidogenesis of cultured human granulosa lutein cells by gonadotropin-releasing hormone analogs. Journal of Clinical Endocrinology and Metabolism 199376 1376-1379.

28 Fraser HM, Sellar RE, Illingworth PJ \& Eidne KA. GnRH receptor mRNA expression by in situ hybridization in the primate pituitary and ovary. Molecular Human Reproduction 19962 117-121.

29 Frederick JL, Hickey MJ, Francis MM, Sauer MV \& Paulson RJ. The effect of leuprolide acetate on steroidogenesis by granulosa and theca cells in vitro. Journal of In Vitro Fertilization and Embryo Transfer 19918 230-234.

30 Torok A, Hamori M, Bodis J, Cledon P, Tinneberg HR \& Hanf V. Effect of LHRH and its analogues on the progesterone secretion of human granulosa cells in vitro. Gynecologic and Obstetric Investigation $199234222-224$.

31 Fabbri R, Porcu E, Pession E, Sereni E, Marsella T, Seracchioli R et al. The effect of leuprorelin on steroidogenesis of human preovulatory granulosa cells in vitro. Journal of Assisted Reproduction and Genetics 199613 287-292.

32 Olsson JH, Akesson I \& Hillensio T. Effects of a gonadotropinreleasing hormone agonist on progesterone formation in cultured human granulosa cells. Acta Endocrinologica 1990 $122427-431$.

33 Guerrero HE, Stein P, Asch RH, de Fried EP \& Tesone M. Effect of a gonadotropin-releasing hormone agonist on luteinizing hormone receptors and steroidogenesis in ovarian cells. Fertility and Sterility $199359803-808$.

34 Gaetje R. Influence of gonadotropin releasing hormone (GnRH) and a GnRH-agonist on granulosa cell steroidogenesis. Clinical and Experimental Obstetrics and Gynecology 199421 164-169.

35 Uemura T, Namiki T, Kimura A, Yanagisawa T \& Minaguchi H. Direct effects of gonadotropin-releasing hormone on the ovary in rats and humans. Hormone Research 199441 7-13.

36 Pellicer A \& Miro F. Steroidogenesis in vitro of human granulosaluteal cells pretreated in vivo with gonadotropin-releasing hormone analogs. Fertility and Sterility $1990 \mathbf{5 4}$ 590-596.

37 Pellicer A, Tarin JJ, Miro F, Sampaio M, Delos Santos MJ \& Remohi J. The use of gonadotropin-releasing hormone analogues (GnRHa), in in vitro fertilization: some clinical and experimental investigations of a direct effect on the human ovary. Human Reproduction 19927 39-47.

38 Hamori M, Torok A, Zwirner M, Batteux C, Schinkmann W \& Bodis J. In vitro progesterone production of human granulosa- 
luteal cells: the impact of different stimulation protocols, poor response and polycystic ovarian syndrome. Human Reproduction $19927592-596$.

39 Dirnfeld M, Goldman S, Gonen Y, Koifman M, Lissak A, Kraiem Z et al. Functional differentiation in progesterone secretion by granulosa versus cumulus cells in the human preovulatory follicle and the effect of different induction of ovulation protocols. Fertility and Sterility 199360 1025-1030.

40 Lin LS, Roberts VJ \& Yen SS. Expression of human gonadotropinreleasing hormone receptor gene in the placenta and its functional relationship to human chorionic gonadotropin secretion. Journal of Clinical Endocrinology and Metabolism $1995 \mathbf{8 0}$ $580-585$.

41 Lin Y, Kahn JA \& Hillensjo T. Is there a difference in the function of granulosa-luteal cells in patients undergoing in vitro fertilization either with gonadotrophin-releasing hormone agonist or gonadotrophin-releasing hormone antagonist? Human Reproduction $1999 \mathbf{1 4} 885-888$.

42 Dor J, Bider D, Shulman A, Levrou JL, Shine S, Mashiach S et al. Effects of gonadotropin-releasing hormone agonists on human ovarian steroid secretion in vivo and in vitro - results of a prospective, randomized in vitro fertilization study. Human Reproduction 200015 1225-1230.
43 Nathwani PS, Kang SK, Cheng KW, Choi KC \& Leung PC. Regulation of gonadotropin-releasing hormone and its receptor gene expression by $17 \beta$-estradiol in cultured human granulosa cells. Endocrinology 2000141 1754-1763.

44 Demirel CL, Weiss JM, Polack S, Unlu C, Diedrich K \& Ortmann O. Effect of the GnRH antagonist ganirelix on cyclic adenosine monophosphate accumulation of human granulosa-lutein cells and cumulus cells. Fertility and Sterility $2000 \mathbf{7 4} 1001-1007$.

45 Emons G, Ortmann O, Schulz KD \& Schally AV. Growthinhibitory actions of analogues of luteinizing hormone releasing hormone on tumor cells. Trends in Endocrinology and Metabolism 19978 355-362.

46 Emons G, Ortmann O, Teichert HM, Fassl H, Löhrs U, Kullander S et al. Luteinizing hormone-releasing hormone agonist triptorelin in combination with cytotoxic chemotherapy in patients with advanced ovarian carcinoma. A prospective double blind randomized trial. Decapeptyl Ovarian Cancer Study Group. Cancer 199678 1452-1460.

Received 9 November 2000

Accepted 2 March 2001 